many years and it can be thoroughly recommended to anyone interested in the conservation of African wildlife. It is to be hoped that its relatively high price will not mean that it will be purchased only by other scientists working on elephants.

S. K. ELTRINGHAM

\title{
The Man Who Loves Giants, by David Shepherd. David and Charles, $£ 4.50$
}

David Shepherd may appear to have joined the ranks of the wildlife conservationists by pure accident, but really it was a case of predestination. He is a man who simply likes to conserve things, whether they are ancient steam engines or endangered animals--especially if they are big ones such as mammoth locomotives and giant elephants. On leaving school he did try to enter conservation by the big front door and flew out to Africa to enlist as a game warden. Having no qualifications he was naturally turned down. He earned his fare home by painting birds, decided to study art and eventually made a living by painting aeroplanes. While doing a commission for the RAF in Nairobi he was asked if, for a change, he would try his hand at elephants. He has never looked back!

This book is not primarily about wildlife: it is the autobiography of a painter who happens also to be a passionate conservationist and who, by his art and his generosity, has made an outstanding contribution to the financing of conservation-particularly in connection with Operation Tiger. As one would expect with such an author, there are copious illustrations in both black and white and colour

G. T. CORLEY SMITH

\section{The Living World of Audubon, by Roland C. Clement. Country Life Books,} $£ 5.95$.

The comparison of painting and photography grinds on, as indeed it always will, because there is an obvious parallel in any visual presentation of life and happening. The scales are recurring ones - the freedom of an artist to create and compose a situation balanced against the sheer scientific exactitude of a photograph.

If an original painting is set against a photograph, the indefinable merits of a painted surface and the individuality of the artist's brushwork combine to devalue the chemical product. A welcome sentimentality is aroused that gives all painters a lift. But here there is something else - both paintings and photographs are reproduced by the same mechanical process; their surfaces are identical. One is left to ponder a purely visual comparison.

Roland Clement has presented something that will delight all who see it. As an experiment in juxtapositions, the choice of Audubon is brilliant, for his painting, perhaps more than any other, distilled every drop of decorative lineal delight from a subject without loss of scientific observation - for a perfect example see the great blue heron on page 31. Moreover he lived before cameras, when artists bore a responsibility to 'record', and before they became confused and manipulated by the camera's split-second caricatures of truth. He looked, closely and clinically, bringing his 'art' to bear not just on the birds but on the flowers and grasses, berries and landscapes of his living world.

Clement has taken only 64 from the 435 species illustrated in the original doubleelephant folios of 'Birds of America', but he has chosen carefully. All the main groups are represented and he has selected for diversity, spectacle and artistic impact. An introduction to each tells of Audubon's own associations with the bird and its status in his day. Then he describes the bird as an object of up-to-date field study, in the form of expanded captions to the supporting photographs. These links are fascinating and beautifully presented, so one sees first the Audubon print, followed by camera portraits from America's leading photographers, showing each subject, 
as Audubon put it, 'at their natural avocations'. Again the choice of photographs is brilliant, for some are almost a perfect facsimile of attitude with the painting; others are wildly contrasted showing the unbelievable range of camera capability in skilled hands.

'The artist paints in order to see better', writes Clement, reminding us of Turner's equally apt comment: 'Every look at nature is a refinement upon art'. This book will certainly give a new boost to the unending, if fascinating, debate, but as a painter I am biased. I still recall the words of a famous and successful wildlife photographer - 'I've just come out of my darkroom and never realised what wonderful things there were in Africa'.

KEITH SHACKLETON

Handbook of the Birds of India and Pakistan, by Salim Ali and S. Dillon Ripley. Vol. 8. Warblers to Redstarts, £8; Vol. 9. Robins to Wagtails, $£ 8.50$; Vol. 10. Flowerpeckers to Buntings, $£ 11.20$. Oxford U.P.

Surface mails having reverted to the pace of sailing days, the final volume of this great work, although published in India in 1974, only reached the FPS after the October issue of Oryx had gone to press. Six years have therefore elapsed since the first two volumes were reviewed here, but there is really very little more to add to one's first impressions. This is an avifauna in the great tradition of Witherby's Handbook of British Birds, with detailed and scrupulously accurate information given under a dozen or so headings - such as field characters, status and distribution, food, voice and breeding. There is a useful cross-reference to a full description of the plumage elsewhere (often to Baker's Fauna of British India), and for the great majority of species both a distribution map and a colour illustration. A commendable feature is that, in order to reduce costs, colour plates from other books, such as Smythies's Birds of Burma, have been cannibalised, and though this leads to occasional duplication and the illustration of less common subspecies, it seems to me wholly justifiable.

Will this, one wonders, be the last regional avifauna on such a scale to succeed in getting published? Both the even more ambitious enterprises for North America and for the Western Palaearctic have run into difficulties, in the latter case largely due to burgeoning printing and other costs. I am sure the authors involved in both would be delighted to think that in six years' time their task would be successfully completed. But then this team has the unique strength of joining the greatest Asian ornithologist of modern times with an outstanding American ornithologist who has achieved the pinnacle of the Secretaryship of the Smithsonian. We expected great things of them, and they have not disappointed us.

RICHARD FITTER

\section{Birds of Prey in Europe, by Maarten Bijleveld. Macmillan, $£ 12.50$}

Very rarely have the fortunes or misfortunes of a group of birds been chronicled in such detail as in this dossier. In Britain we already know quite a large part of the story of the recent declines in our raptors, and now the appalling story of their systematic persecution throughout Europe is narrated in full. Both in Britain and continental Europe persecution continues on big shooting estates. Dr Bijleveld gives all the details of continuing habitat destruction, all the details of the deliberate use of poisons, all the details of deaths resulting from the use and misuse of organochlorine pesticides. He points out, too, the increasing disturbance at the nests of rare birds of prey by ornithologists taking advantage of cheap travel offered by package tours; travelling educates, but a code of behaviour seems essential. But he fails to mention the problem caused by the rash of zoos and bird gardens all wanting eagles and vultures as a public attraction. Nor does he mention as a problem the increasing demands for falconry. Perhaps this problem is not general in Europe and perhaps the 